\title{
Biodegradation of bottom sediments of Turawa Lake
}

\author{
Adam Latała, Sławomir Wierzba \\ Opole University, Chair of Biotechnology and Molecular Biology, ul. Kominka 4, 45-032 Opole, Poland, \\ tel. +48 7740160 50; e-mail: kbsie@uni.opole.pl
}

\begin{abstract}
In this work we tested biopreparations developed in our laboratory for their ability to degrade the organic matter of the bottom sediments of Turawa Lake. The biodegradation was conducted under laboratory conditions for 6 weeks. For the testing purposes, there were three variants of biopreparations that contained autochthonous strains originating from our own collection and their mixture. The testing showed that the introduction of the biopreparations to the bottom sediment resulted in a significant increase of the number of bacteria, which consequently brought about the reduction of organic compounds in the sediment. In the case of all the variants, the number of bacteria increased by order of $10^{2}-10^{4} \mathrm{CFU} / \mathrm{g}$ after 42 days of biodegradation. Among the tested biopreparations, the most effective one was the mixture of the autochthonous strains and those originating from the collection. After biopreparation was applied, a drop of content of carbohydrates by $66.94 \%$, fatty matter by $83.33 \%$ and proteins by $74.42 \%$ was noted.
\end{abstract}

Keywords: bottom sediments, biopreparation, biodegradation.

Presented at VII Conference Wasteless Technologies and Waste Management in Chemical Industry and Agriculture, Międzyzdroje, 12 - 15 June, 2007.

\section{INTRODUCTION}

Turawa Lake is one of three large buffer reservoirs in the Opole area. The bottom sediments forming an integral part of the aquatic ecosystem have been accumulating on its bottom since its creation. They participate in the circulation of the matter in the lake and, in consequence, may materially affect the water quality. The quantity and the composition of the sediments depend, among other things, on the geological and morphological structure of the drainage area, the shape of the reservoir basin, its fertility, climatic conditions, the type of the plant cover, and the anthropogenic influence ${ }^{1-2}$. The basic problem concerning this type of reservoirs is the progressing eutrophication resulting mainly from an excessive load posed on the lake by the organic and biogenic matter. In consequence, the reservoir gradually degrades and the mudding process intensifies. The eutrophication processes of the lake may be inhibited by decreasing the load of biogens from external sources (surface affluents, groundwater, sewage discharge) and the reduction of the organic matter content within the reservoir ${ }^{2}$. The bottom sediments of Turawa Lake are in a form of the dark grey finegrained mud consisting of mineral and organic matter. The organic matter content in the sediments ranges from 20 to $25 \%$; it includes mainly carbohydrates, proteins and fats. Therefore, one of the methods to reduce the quantity of organic compounds in the sediments may be their biodegradation because the compounds biodegrade in almost $90 \% \%^{3-4}$ under appropriate conditions. Thus, it would be economically justified to make use of the biodegradation by an introduction of the biopreparation containing strains of cellulolytic, lipolytic and proteolytic bacteria to the bottom sediment. The objective of the tests conducted was to assess the efficiency of the biodegradation of the organic compounds contained in the bottom sediments of Turawa Lake using the developed bacterial biopreparations.

\section{MATERIALS AND METHODS}

The tested material consisted of the bottom sediments sampled from three spots located in the north-western part of Turawa Lake, at the depth of 5-6 m. Then, the sediment was dried and powdered, obtaining ca. $10 \mathrm{~kg}$ of material for further tests. The sediment contained ca. 25\% of organic compounds, mainly carbohydrates, proteins and fatty matter. The biodegradation of sediments made use of 3 variants of biopreparations containing strains of cellulolytic, lipolytic and proteolytic bacteria isolated from the bottom sediments and originating from our own collection of the Biotechnology Institute. The lipolytic and proteolytic bacteria were isolated on a mineral nutrient medium $^{5-6}$. The cellulolytic bacteria were isolated on the Waksman medium ${ }^{7}$ and then in a liquid medium of the following composition: $\mathrm{KNO}_{3}-2.5 \mathrm{~g} / \mathrm{dm}^{3}, \mathrm{KH}_{2} \mathrm{PO}_{4}$ $1.0 \mathrm{~g} / \mathrm{dm}^{3}, \mathrm{MgSO}_{4} \times 7 \mathrm{H}_{2} \mathrm{O}-0.3 \mathrm{~g} / \mathrm{dm}^{3}, \mathrm{CaCl}_{2}-0.1 \mathrm{~g} /$ $\mathrm{dm}^{3}, \mathrm{NaCl}-0.1 \mathrm{~g} / \mathrm{dm}^{3}, \mathrm{FeCl}_{3}-0.01 \mathrm{~g} / \mathrm{dm}^{3}$, potato starch $-20.0 \mathrm{~g} / \mathrm{dm}^{3}$, cellulose filters, $\mathrm{pH}$ 7.2. Among the isolated bacteria, the strains of the highest enzymatic activity were the basis to develop the following three microbiological preparations: $\mathrm{KA}$ - containing the strains isolated from the lake; KM - containing the strains originating from the collection; and KMA - containing the mixture of the strains from the collection and the autochthonous strains. All the strains were cultured individually in an enriched broth bouillon ${ }^{8}$ with shaking to a density of $10^{9} \mathrm{CFU} / \mathrm{ml}$, and then were subject to lyophilisation in a vacuum freeze dryer, type LB-4. The obtained biopreparations contained the following strains: Acinetobacter lwoffii, Pseudomonas fluorescens, Pantoea sp., Bacillus sp., Serratia liquefaciens, Cytophaga sp., Cellulomonas sp.. The biodegradation of the sediments was conducted under laboratory conditions in four glass containers, each of $10 \mathrm{dm}^{3}$ in volume, to which $2 \mathrm{~kg}$ of the sediment and $5 \mathrm{dm}^{3}$ of water from the lake were introduced. Then, to the 3 containers KA, KM and KMA biopreparations in the amount of $0.001 \%$, were added, respectively, whereas the forth one was a control test. The biodegradation was carried out for 6 weeks at 
$20^{\circ} \mathrm{C}$, with quantitative microbiological and chemical analyses of the sediments, conducted every 14 days. The microbiological tests were carried out using the cultureplate methoud based on PN-75/C-046159. The following quantities of bacteria were measured: the total number of the bacteria (TNB) on a nutrient agar, the total number of the lipolytic bacteria on a substrate with tributyrin ${ }^{8}$ and the total number of the proteolytic bacteria on an agar substrate with milk ${ }^{8}$. The number of the cellulolytic bacteria was determined by the titre method, on a Winogradzki nutrient medium with the blotting paper strips, specifying the socalled most probable number (MPN) of the bacteria in $1 \mathrm{~g}$ of the sediment, read from Mc'Crady tables ${ }^{8}$. The chemical tests included: determination of the quantity of the fatty matter soluble in petroleum benzine, based on PN-76R-64753 ${ }^{10}$; the determination of the quantity of the proteins based on PN-ISO-59/83'1 ; the determination of the quantity of carbohydrates made by the anthrone method $^{12}$.

\section{RESULTS AND DISCUSSION}

Depending on the type of the bioprepara-tion used, the intensity of the biodegradation process of organic compounds in the bottom sediments of Turawa Lake varied (Table 1, Fig. 1, 2 and 3). The organic matter produced in situ in the lakes and coming from the out-side by surface water includes mainly carbo-hydrates (polysaccharides such as cellulose) ${ }^{2}$. Their initial content in the sediments amounted to $190 \mathrm{~g} / \mathrm{kg}$ of d.m. In successive weeks, a continuing drop of carbohydrate content in all variants with the biopreparations was observed. According to many authors ${ }^{3-13-14}$, enrichment of the natural microflora with a biopreparation containing microorganisms of high enzymatic activity significantly accelerated the biodegradation processes. The highest intensity of carbohydrate decomposition was observed after an application of the biopreparation that was the mixture of the bacteria isolated from the sediments of the lake and our own collection (KMA variant). The quantity of the carbohydrates dropped to $138.6 \mathrm{~g} / \mathrm{kg}$ of d.m. after 14 days and to $62.8 \mathrm{~g} / \mathrm{kg}$ of d.m. after 42 days, which corresponded to the reduction of $27.03 \%$ and $66.94 \%$, respectively. A slightly lower reduction, in similar time intervals, was determined in the case of KM variant: $24.84 \%$ and $58.84 \%$. The quantity of carbohydrates dropped to $142.8 \mathrm{~g} / \mathrm{kg}$ of d.m. and $78.2 \mathrm{~g} / \mathrm{kg}$ of d.m., respectively. Definitely, the lowest efficiency in the decomposition of carbohydrates was shown by the variant with the biopreparation containing only the autochthonous strains (KM variant). The observed reduction was from $8.47 \%$ to $25.73 \%$ lower in comparison with the KMA variant and the biodegradation amounted to $41.21 \%$ at the end of the biodegradation. In the control sys-tem, the reduction of carbohydrates was small and reached from $2.05 \%$ after 2 weeks to $5.89 \%$ after 6 weeks of biodegradation (Table 1, Fig. 1).

The introduction of biopreparations to the sediment material resulted in an intense decomposition process of monosaccharides and polysaccharides, particularly in the first weeks of biodegradation. Similar results were noted by Wierzba and Nabrdalik ${ }^{15}$ while composting the household waste using the bacterial biopreparation. The reduction of carbohydrates was most intense in the first weeks
Table 1. Biodegradation of carbohydrates, the fatty matter and protein in the Turawa Lake sediments

\begin{tabular}{|c|c|c|c|c|}
\hline \multirow{2}{*}{ Variant } & \multirow{2}{*}{$\begin{array}{c}\text { Time } \\
\text { [in days] }\end{array}$} & \multicolumn{3}{|c|}{$\begin{array}{l}\text { Substrate content In bottom sediment } \\
\text { [g/kg of d.m.] }\end{array}$} \\
\hline & & $\begin{array}{l}\text { carbohydrat } \\
\text { es }\end{array}$ & $\begin{array}{l}\text { fatty } \\
\text { matter }\end{array}$ & proteins \\
\hline \multirow{4}{*}{ Control } & 0 & 190.0 & 5.4 & 8.6 \\
\hline & 14 & 186.1 & 4.9 & 7.2 \\
\hline & 28 & 183.1 & 4.3 & 6.4 \\
\hline & 42 & 178.8 & 2.9 & 4.2 \\
\hline \multirow{4}{*}{$\mathrm{KA}$} & 0 & 190.0 & 5.4 & 8.6 \\
\hline & 14 & 154.7 & 3.5 & 6.5 \\
\hline & 28 & 133.5 & 2.5 & 5.5 \\
\hline & 42 & 111.7 & 2.1 & 2.6 \\
\hline \multirow{4}{*}{$\mathrm{KM}$} & 0 & 190.0 & 5.4 & 8.6 \\
\hline & 14 & 142.8 & 4.3 & 7.0 \\
\hline & 28 & 108.7 & 4.2 & 6.4 \\
\hline & 42 & 78.2 & 2.6 & 3.2 \\
\hline \multirow{4}{*}{ KMA } & 0 & 190.0 & 5.4 & 8.6 \\
\hline & 14 & 138.6 & 4.5 & 7.9 \\
\hline & 28 & 102.2 & 2.4 & 3.8 \\
\hline & 42 & 62.8 & 0.9 & 2.2 \\
\hline
\end{tabular}

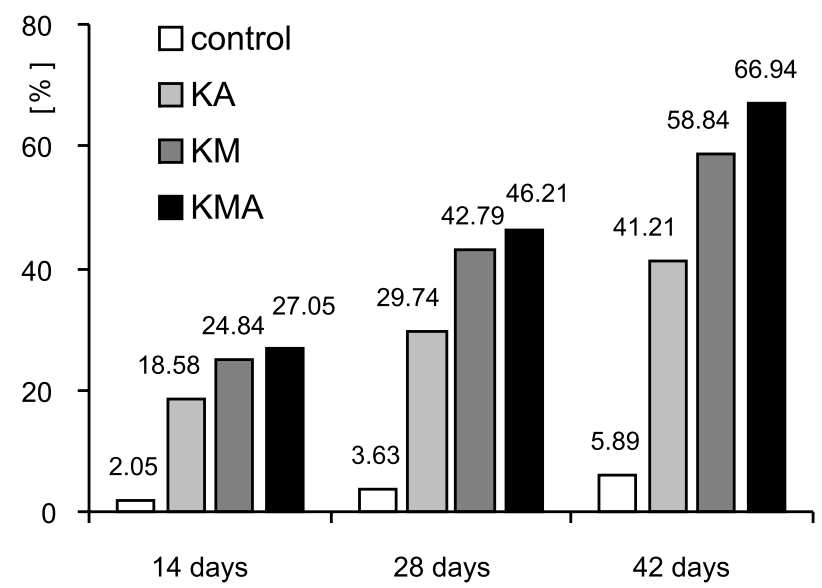

Figure 1. The percentage of the carbohydrate mass reduction during the biodegradation (see Table 1)

of the process and reached $38.5 \%$ after 30 and $47.5 \%$ after 60 days of biodegradation. This regularity is also confirmed by other authors ${ }^{7-16}$. The results obtained show a considerable contribution of the cellulolytic bacteria strains from our own collection in the biodegradation of carbohydrates. Oxygen decomposition of the compounds by the Cellulomonas and Cytophaga bacterial occurred more intensely in comparison with the strains isolated from the environment. It is widely known that aerobic mineralization processes are much faster and more effective than the anaerobic processes ${ }^{5-13}$. The fatty matter content in the bottom sediments was low and amounted to $5.4 \mathrm{~g} / \mathrm{kg}$ of d.m. After the first 14 days of biodegradation, the highest reduction was noted after the application of the biopreparation containing the autochthonous strains (KM variant) and amounted to $35.18 \%$, with the quantity of the fatty matter dropping to $3.5 \mathrm{~g} / \mathrm{kg}$ of d.m. For the remaining variants: KM and KMA, the decrement of fat was significantly lower and ranged from $16.17 \%$ to $20.37 \%$. In the successive weeks of the experiment, the continuing drop of the quantity of fat was observed in the KA and KMA variants. Finally, after 42 days of biodegradation, the fat quantity reached $2.1 \mathrm{~g} / \mathrm{kg}$ of d.m. and 0.9 $\mathrm{g} / \mathrm{kg}$ of d.m., respectively, which corresponded to the reduction of $61.11 \%$ and $83.33 \%$, respectively. In the case 
of the variant with the biopreparation containing the strains from the collection (KM variant), fat reduction after 42 days reached $51.85 \%$ and was slightly higher than the result of the control test: $46.30 \%$ (Table 1, Fig. 2).

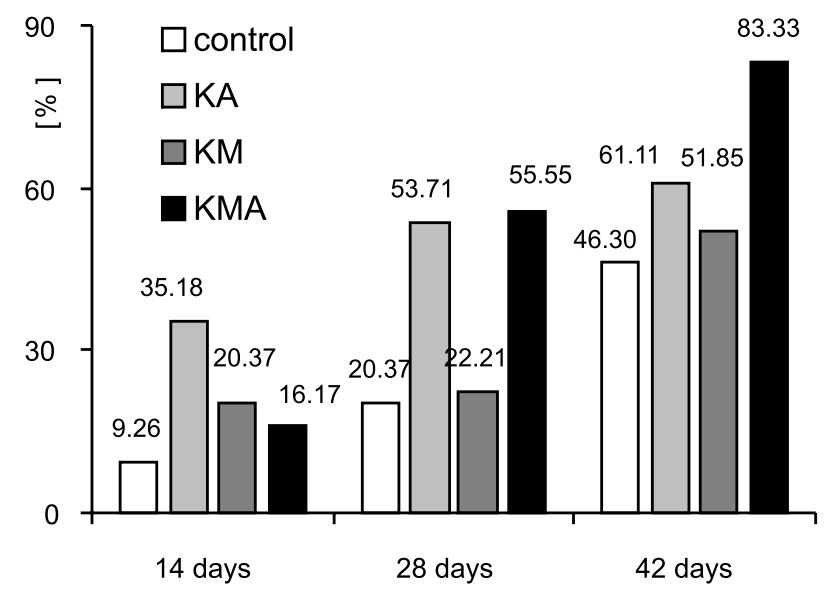

Figure 2. The percentage of the fatty matter reduction during the biodegradation (see Table 1)

In other tests conducted by the same team of authors ${ }^{\mathbf{1 3}}$ regarding the biodegradation of fatty waste using the mixture of autochthonous strains and strains from the collection, very similar fat reduction was achieved. After 44 days of composting, the reduction ranged from $67.7 \%$ to $87.1 \%$ depending on the applied organic components. Comparable results were obtained by Patorczyk-Pytlik et al. ${ }^{16}$ after 4 months of composting the fatty sediments; the reduction of fatty matter was around $80-90 \%$. However, Bernal et al. ${ }^{17}$ noted a considerably lower reduction of about $50 \%$ after 56 days of biodegradation of the sewage sediments with bioactivators added. Furthermore, Wierzba and Nabrdalik ${ }^{\mathbf{1 5}}$ noted only $32.6 \%$ fat decrement after 60 days of the mineralisation of organic waste with biopreparation added. The biodegradation of proteins in the tested bottom sediment with the initial quantity of 8.6 $\mathrm{g} / \mathrm{kg}$ of d.m. had a similar course as the biodegradation of fatty matter. In the first 2 weeks, the highest drop of protein content to $7.1 \mathrm{~g} / \mathrm{kg}$ of d.m. was again determined in the case of the KA variant. In the next 2 weeks, its decrement was much lower, but it was observed regularly. Almost a two-fold increase of protein reduction was determined in the last week of biodegradation and finally, after 42 days, it reached $69.76 \%$ and the quantity of the proteins amounted to $2.6 \mathrm{~g} / \mathrm{kg}$ of d.m. A similar drop of the protein content was noted in the KMA variant. Although its initial reduction was small and amounted to $8.14 \%$, it increased to $55.81 \%$ after 4 weeks to reach the final level of $74.42 \%$, which corresponded to the quantity of proteins: $2.2 \mathrm{~g} / \mathrm{kg}$ of $\mathrm{d} . \mathrm{m}$. The protein reduction in the $\mathrm{KM}$ variant was similar to the fatty matter reduction. On the $14^{\text {th }}$ and $28^{\text {th }}$ day of the biodegradation, its quantity was on the level of the control test and amounted to 7.0 $\mathrm{g} / \mathrm{kg}$ of d.m. and $6.4 \mathrm{~g} / \mathrm{kg}$ of d.m., respectively; only after 42 days, the reduction was about $11 \%$ higher in the control test and reached $62.79 \%$ (Table 1, Fig. 3). A comparable (ca. 49\%) decrement of proteins was noted by Wierzba and Nabrdalik ${ }^{\mathbf{1 5}}$ after 30 days of the biodegradation of the organic waste with the biopreparation added. Other tests conducted by Latała et al. ${ }^{7}$ concerning the biodegradation of the household waste also showed that after 28 days, protein reduction ranged from $49 \%$ to $55 \%$ for the biopreparations containing the autochthonous strains and their mixture with the strains from the collection. Both the results of the biodegradation of the fat and the proteins indicate that the decomposition of the compounds occurred with the high share of the appropriately selected and adapted autochthonous strains. According to many authors ${ }^{5-18}$, only the adaptation of the microflora isolated directly from the waste provided satisfactory results of the biodegradation of the organic matter.

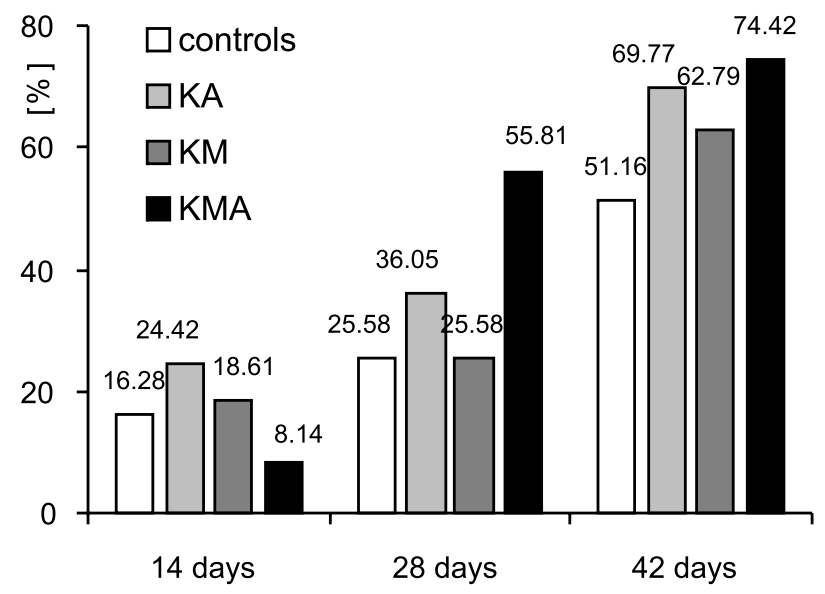

Figure 3. The percentage of the protein mass reduction during biodegradation (see Table 1)

Quantitative microbiological tests of the bottom sediments of Turawa Lake presented in Table 2, show a significant growing tendency of the total number of bacteria (TNB) in the case of all the variants in the course of biodegradation. A minor drop of the quantity of the bacteria was observed only in the control test and the KM variant on the $42^{\text {nd }}$ day of testing. The highest increase of TNB took place between the $14^{\text {th }}$ and the $28^{\text {th }}$ day of biodegradation. The number of the bacteria increased about 50- to 150-times in the case of all the variants containing the biopreparations. Finally, at the end of the biodegradation, the number of the bacteria ranged from $5.50 \times 10^{6} \mathrm{CFU} / \mathrm{g}$ in the case of the $\mathrm{KM}$ variant to $2.67 \times 10^{8}$ $\mathrm{CFU} / \mathrm{g}$ in the case of the KMA variant, and was about 20to 1000 -times higher in comparison with the control test by (Table 2). Similar results were noted by Jorgensen et al. ${ }^{19}$ when composting the oiled waste using the bacterial biopreparations. Moreover, Olańczuk-Neyman et al. ${ }^{\mathbf{2 0}}$ determined the number of heterotrophic bacteria in port sediments at the level of $10^{8} \mathrm{CFU} / \mathrm{g}$. When composting the organic waste with the microbiological inoculum added, after about 2 months of composting, Stuczyński ${ }^{21}$ determined a considerably higher number of bacteria ranging from $10^{9}$ to $10^{10} \mathrm{CFU} / \mathrm{g}$. The introduction of biopreparations positively affected the quantity of the cellulolytic, lipolytic and proteolytic bacteria in the course of the biodegradation of the sediments. A systematic increase of their number and the percentage in TNB was noted in the case of almost all variants being tested.

The initial content of individual groups of the microorganisms in the TNB was within the range from $4.69 \%$ to $12.98 \%$, which corresponded to the quantity of bacteria of $10^{3} \mathrm{CFU} / \mathrm{g}$. During the next weeks of biodegradation, the course of the quantitative changes of the cellulolytic, lipo- 
Table 2. The quantity of the bacterial strains during the biodegradation process of the lake sediments

\begin{tabular}{|c|c|c|c|c|c|}
\hline Variant & $\begin{array}{c}\text { The time of } \\
\text { Biodegradation [in } \\
\text { days] }\end{array}$ & $\begin{array}{l}\text { The total number of } \\
\text { bacteria } \\
\text { [CFU/g] }\end{array}$ & $\begin{array}{l}\text { The total number of } \\
\text { lipolytic bacteria } \\
\text { [CFU/g] }\end{array}$ & $\begin{array}{c}\text { The total number of } \\
\text { proteolytic } \\
\text { bacteria [CFU/g] }\end{array}$ & $\begin{array}{c}\text { The MPN of cellulolytic } \\
\text { bacteria in } 1 \mathrm{~g} \text { of the } \\
\text { sediment }\end{array}$ \\
\hline \multirow{4}{*}{ Control } & 0 & $4.63 \times 10^{4}$ & $3.28 \times 10^{3}$ & $5.28 \times 10^{3}$ & $1.20 \times 10^{3}$ \\
\hline & 14 & $2.18 \times 10^{5}$ & $1.14 \times 10^{4}$ & $2.43 \times 10^{4}$ & $8.00 \times 10^{3}$ \\
\hline & 28 & $1.52 \times 10^{6}$ & $1.88 \times 10^{5}$ & $1.62 \times 10^{5}$ & $3.20 \times 10^{4}$ \\
\hline & 42 & $2.50 \times 10^{5}$ & $2.51 \times 10^{4}$ & $2.50 \times 10^{4}$ & $1.20 \times 10^{4}$ \\
\hline \multirow{4}{*}{$\mathrm{KA}$} & 0 & $2.00 \times 10^{4}$ & $1.44 \times 10^{3}$ & $2.44 \times 10^{3}$ & $1.10 \times 10^{3}$ \\
\hline & 14 & $4.87 \times 10^{5}$ & $6.12 \times 10^{4}$ & $1.01 \times 10^{5}$ & $3.60 \times 10^{4}$ \\
\hline & 28 & $2.70 \times 10^{7}$ & $4.57 \times 10^{6}$ & $4.20 \times 10^{6}$ & $2.42 \times 10^{6}$ \\
\hline & 42 & $5.43 \times 10^{\prime}$ & $7.68 \times 10^{6}$ & $9.82 \times 10^{6}$ & $4.91 \times 10^{6}$ \\
\hline \multirow{4}{*}{ KM } & 0 & $7.25 \times 10^{4}$ & $4.68 \times 10^{3}$ & $7.10 \times 10^{3}$ & $3.40 \times 10^{3}$ \\
\hline & 14 & $4.24 \times 10^{5}$ & $4.61 \times 10^{4}$ & $5.90 \times 10^{4}$ & $2.70 \times 10^{4}$ \\
\hline & 28 & $6.25 \times 10^{7}$ & $8.85 \times 10^{6}$ & $5.75 \times 10^{6}$ & $6.52 \times 10^{6}$ \\
\hline & 42 & $5.50 \times 10^{6}$ & $6.25 \times 10^{5}$ & $6.32 \times 10^{5}$ & $5.80 \times 10^{5}$ \\
\hline \multirow{4}{*}{ KMA } & 0 & $4.62 \times 10^{4}$ & $4.42 \times 10^{3}$ & $6.00 \times 10^{3}$ & $2.80 \times 10^{3}$ \\
\hline & 14 & $4.02 \times 10^{6}$ & $6.52 \times 10^{5}$ & $8.09 \times 10^{5}$ & $2.10 \times 10^{5}$ \\
\hline & 28 & $1.82 \times 10^{8}$ & $3.93 \times 10^{7}$ & $3.79 \times 10^{7}$ & $2.20 \times 10^{7}$ \\
\hline & 42 & $2.67 \times 10^{8}$ & $6.31 \times 10^{7}$ & $5.48 \times 10^{7}$ & $3.00 \times 10^{7}$ \\
\hline
\end{tabular}

lytic and proteolytic bacteria was similar as in the case of the TNB. After 4 weeks of biodegradation, the number of microorganisms in the case of the KA and KMA increased, whereas it slightly dropped in the case of the KM variant. The highest number of the cellulolytic bacteria was observed at the end of the biodegradation in the case of the KMA variant and reached $3.00 \times 10^{7} \mathrm{CFU} / \mathrm{g}$, whereas the percentage in TNB amounted to $11.23 \%$. In case of the remaining groups of bacteria, the highest number was also determined after application of the biopreparation that contained the mixture of autochthonous strains and strains from the collection. After 6 weeks of biodegradation, the number of bacteria exceeded $10^{7} \mathrm{CFU} / \mathrm{g}$, with a content of over $20 \%$ in TNB, and in comparison with the control variant this number was over 1000-times higher (Table 2, Fig. 4, 5 and 6).

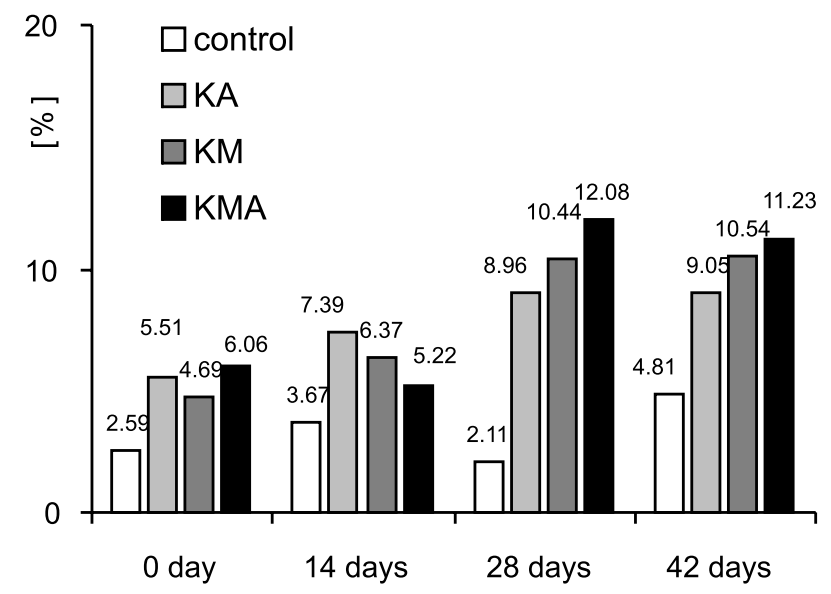

Figure 4. Percentage of cellulolytic bacteria in TNB

Slightly lower results were noted by Latała et al. ${ }^{3}$ during the $44^{\text {th }}$ biodegradation of fatty waste using the biopreparation; the number of lipolytic bacteria reached $10^{6} \mathrm{CFU} / \mathrm{g}$ and was about 660-times higher than that determined in the control test. According to tests of Wierzba and Nabrdalik ${ }^{\mathbf{1 5}}$, the number of bacteria decomposing carbohydrates, proteins and fats after 60 days of biodegradation range from $10^{6}$ to $10^{8} \mathrm{CFU} / \mathrm{g}$, but it was only about 10-times higher than that determined in contol test (which did not contain the biopreparation). The results obtained in our own tests suggest that the efficiency of the organic matter biodegradation in the bottom

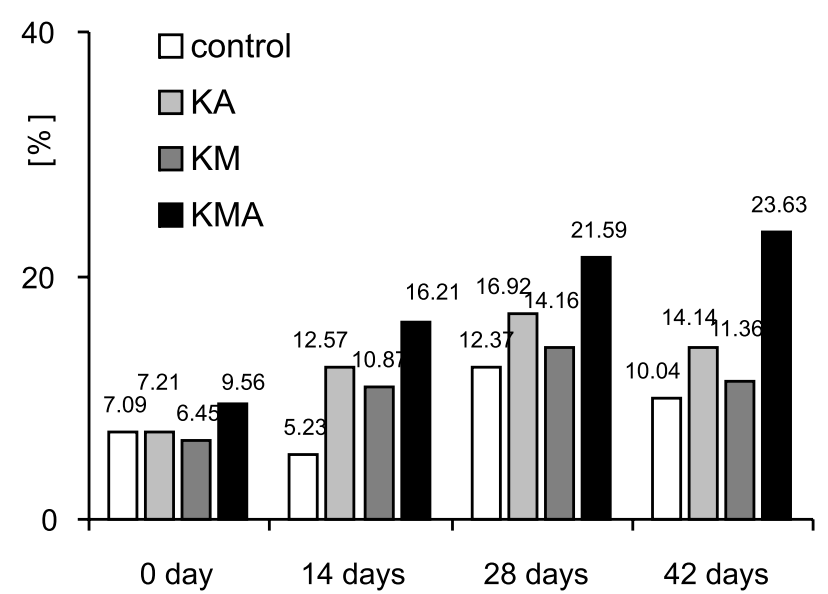

Figure 5. Percentage of lipolytic bacteria in TNB

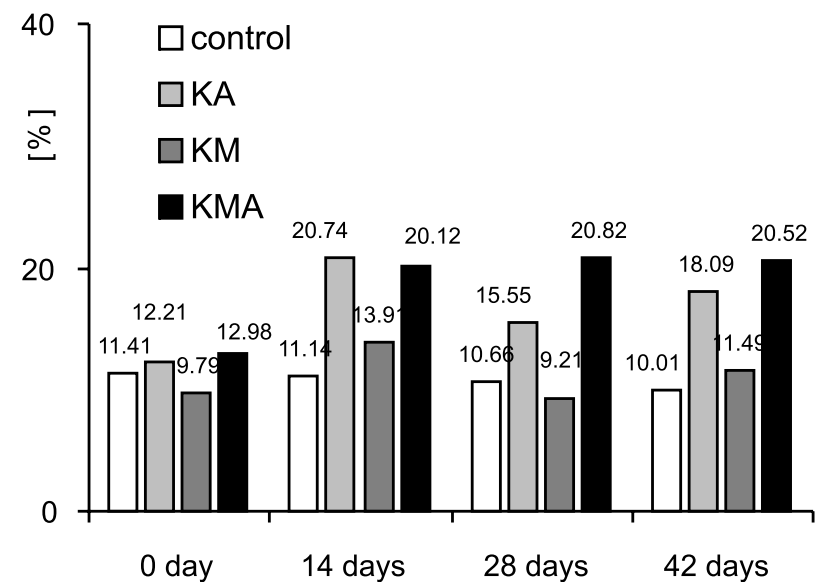

Figure 6. Percentage of proteolytic bacteria in TNB

sediments depended on the number of the bacteria and their qualitative content ${ }^{7-18-20}$.

\section{CONCLUSIONS}

The bottom sediments of Turawa Lake include mainly the fine-grained sapropelic mud that hinders oxygen access to the deeper layers of the sediments; therefore the natural processes of the organic matter mineralisation are very slow there. The conducted laboratory tests of biopreparations demonstrated their high efficiency in the decomposition of the organic matter contained in the 
sediments. We found that the highest intensity of the organic matter decomposition was demonstrated by the biopreparation that was the mixture of the bacteria isolated from the sediments of the lake and the bacteria obtained from our own collection (KMA variant). At the end of the 42-day degradation process the content of the carbohydrates, fatty matter and protein was reduced by $66.97 \%, 83.33 \%$ and $74.42 \%$, respectively. In comparison with the control test, the efficiency of the biodegradation process was $23.26-37.03 \%$ higher, whereas in the case of carbohydrates, the difference reached as much as $61.05 \%$, after 6 weeks of the experiment commencement. The reduction of the carbohydrates mass was most intense during the 14 days from the beginning of the process and reached $27.05 \%$. The biodegradation processes were accompanied by a significant rise of the TNB, including also the cellulolytic, lipolytic and proteolytic bacteria. The high dynamics of the process was shown mainly by the KMA biopreparation. At the end of the biodegradation, the number of the bacteria reached $2.67 \times 10^{8} \mathrm{CFU} /$ $\mathrm{g}$, which was about 1000-times higher in comparison with the control test. In this biopreparation the content of the cellulolytic, lipolytic and proteolytic bacteria in the total number of all the bacteria was $11.23 \%, 23.63 \%$ and $20.52 \%$, respectively. The efficiency of the organic matter biodegradation in the bottom sediments depended on the quantity of bacteria and the composition of the species and their strains. Assuming a high load of the bottom sediments of Turawa Lake with the biogens, the application of the biopreparation for the decomposition of the organic compounds in the water and the sediments, seems to be a rational and effective reduction method. However, owing to the unfavourable physical structure of the sediments, it would be necessary to ensure the optimum conditions for the development of the microorganisms, for example by an improvement of oxygen conditions on the deeper levels of the reservoir.

\section{LITERATURE CITED}

(1) Korzeniewska E., Gotkowska-Plachta A.: Ocena sanitarno-bakteriologiczna osadów dennych Jeziora Wigry w latach 1998 - 1999, Archiwum Ochrony Środowiska, 2004, vol. $30(4), 73-83$.

(2) Sobczyński T., Zioła A.: Kumulacja materii organicznej w osadzie dennym jeziora, Ekologia i Technika, 2004, vol. $\mathrm{XV}, \mathrm{nr}$ 5, $135-140$.

(3) Latała A., Wierzba S., Polaczek B.: Uwarunkowania bioutylizacji odpadów tłuszczowych w warunkach laboratoryjnych, Zesz. Prob. Post. Nauk Rol., 2001, 477, 397 $-403$.

(4) Wierzba S., Latała A., Latała B.: Wpływ dodatku węgla brunatnego i torfu na bioutylizację odpadów tłuszczowych wstępne badania laboratoryjne. Biotechnologia, 2000, 3(50), $193-201$.

(5) Latała A., Wierzba S., Latała B.: Biological utilisation of fatty waste - initial laboratory examination, Biotechnologia, 2000, 1(48), 124 - 134.

(6) Latała A., Wierzba S.: Ocena aktywności biodegradacyjnej wybranych szczepów bakterii lipolitycznych, Biotechnologia, 2004, 3(66), 193 - 201.

(7) Latała A., Wierzba S., Farbiszewska T., Polaczek B., Boniewska E.: Biodegradacja odpadów gospodarczych przy użyciu szczepów bakterii lipolitycznych, proteolitycznych i celulolitycznych, Bio-technologia, 2004, 3(66), 202 - 213.
(8) Burbianka M., Pliszka A., Murzyńska H.: Mikrobiologia żywności. Państwowy Zakład Wydawnictw Lekarskich, Warszawa, 1983.

(9) PN-75/C-04615, Badania mikrobiologiczne. Oznaczanie ogólnej liczby bakterii metoda płytkową.

(10) PN-76/R-64753, Oznaczanie zawartości tłuszczu surowego.

(11) PN-ISO-59/83. Oznaczanie zawartości azotu i obliczanie zawartości białka ogólnego.

(12) Kłyszejko-Stefanowicz L.: Cwiczenia z biochemii. PWN, Warszawa, 1980.

(13) Gostkowska K., Szwed A., Wyczółkowski A.: Próba kompostowania odpadów tytoniowych. Cz. III. Wpływ stosowania szczepionki na rozwój mikroorganizmów i niektóre właściwości chemiczne kompostu z odpadów tytoniowych, Zesz. Prob. Post. Nauk Rol., 1996, 437, 159 - 165.

(14) Riis V., Brandt M., Miethe D., Babel W.: Influence of special surfactants on the microbial degradation of mineral oils, Chemosphere, 2000, 41, 1001 - 1006.

(15) Wierzba S., Nabrdalik M.: Biocomposite for organic waste degradation, Fizykochemiczne Problemy Metalurgii, 2005, 39, 249 - 256.

(16) Patorczyk-Pytlik B., Spiak Z., Gediga K.: Ocena możliwości rolniczego wykorzystania osadów ściekowych z zakładu przetwórstwa drobiowego. Cz. I. Wpływ procesu kompostowania na zmiany składu chemicznego osadów przemysłu drobiowego, Fol. Univ. Agric. Stetin. 200 Agricultura, 1999, 77, 311 - 316.

(17) Bernal M.P., Navarro A.F., Sanczez-Monedero M.A., Roig A., Cegarra J.: Infulence of sewage sludge compost stability and maturity on carbon and nitrogen mineralization in soil, Soil Biol. Bio-chem., 1998, 30(3), 305 - 313.

(18) Farbiszewska T., Farbiszewska-Bajer J., Sudoł T.: Biodegradacja substancji tłuszczowych z gruntów - izolowanie mikroorganizmów biodegradujących substancje tłuszczowe, Fizykochemiczne Problemy Mineralurgii, 1995, 29, 151 - 156.

(19) Jorgensen K.S., Puustinen J., Suortti A.M.: Bioremediation of petroleum hydrocarbon-contaminated soil by composting in biopiles, Environmental Pollution, 2000, 107, $245-254$.

(20) Olańczuk-Neyman K., Mazurkiewicz B.: Badania osadów portowych $\mathrm{w}$ aspekcie możliwości zastosowania bioremediacji, International Conference on Analysis and Utilization of Oil Wastes, AUZO'96, 1996, 316 - 321.

(21) Stuczyński T.: Wpływ stosowania różnego rodzaju inoculum na przebieg procesu kompostowania i jakość uzyskanego produktu, Pam. Puł., 1992, 100, 217 - 225. 